\title{
Topography of the medullary cone of the feline night monkey: Clinical implications in epidural anesthesia*
}

\section{Topografia do cone medular do macaco-da-noite: auxiliando a abordagem peridural}

\author{
Daniela Regina Costa e Silva, ${ }^{* *}$ Carlos Felipe dos Santos de Campos Ribeiro, ${ }^{* * *}$ Paola Cardias Soares, ${ }^{* \star * *}$ \\ Ana Rita de Lima, ${ }^{* * * *}$ Érika Branco******
}

\begin{abstract}
Feline night monkey (Aotus azarae infulatus) is an arboreal primate that sleeps during the day hidden among branches of trees, leaving its hideout after nightfall. Little is known about the morphology of these animals, which leads to some difficulty in clinical and surgical approaches, as there has been substantial growth in the veterinarian's role in maintaining the health and well-being of wildlife. Thus, we sought to investigate the topography and morphometry of the medullary cone, a small portion of the nervous system of the feline night monkey, which is of paramount importance in approaches for epidural anesthesia. Specimens from five young females were used, each with eight lumbar vertebrae, three sacral vertebrae, and a medullary cone with an average length of $7.5 \mathrm{~cm}$, located between L5 and S3. Based on this finding, we suggest that a probable site for the application of epidural anesthesia is the space between S3 and Cc1.
\end{abstract}

Keywords: Aotus azarae infulatus, lumbar intumescence, nervous system, epidural anesthesia.

\begin{abstract}
Resumo
O macaco-da-noite (Aotus azarae infulatus) é um animal arborícola que dorme durante o dia escondido entre os ramos, saindo do esconderijo após o anoitecer. Pouco se sabe sobre a morfologia destes animais, o que gera certa dificuldade nas abordagens clínico-cirúrgicas, uma vez que cresce substancialmente o papel do médico veterinário nas questões de saúde e bem-estar de animais selvagens. Visando contribuir com esses profissionais, buscou-se investigar a topografia e morfometria de uma pequena porção do sistema nervoso do macaco-da-noite, o cone medular, que é de suma importância nas abordagens quanto à anestesia peridural. Foram utilizados cinco espécimes fêmeas, jovens, de macaco-da-noite, que apresentavam oito vértebras lombares e três vértebras sacrais, e cone medular possuindo em média de 7,5 cm de comprimento, localizando-se entre L5 e S3. Este achado nos leva a sugerir como sítio provável para a aplicação de anestesia epidural, o espaço entre S3 e Cc1.
\end{abstract}

Palavras-chave: Aotus azarae infulatus, intumescência lombar, sistema nervoso, anestesia peridural.

\section{Introduction}

The night monkeys are the only nocturnal primates of the New World, and their remarkably large eyes are similar to the nocturnal prosimian primates of the Old World (Bicca-Marques, 2006). Geographically distributed through the Amazon and the Cerrado, night monkeys may become extinct both through biopiracy and the urban expansion of this region due to the implementation of agricultural, mining, and hydroelectric power plant construction projects (Pinto e Kzam, 2012).

This intense process of urbanization in the Amazon has led to massive human interference in the habitat of these species with the hunting, trade, and peddling of these individuals as pets. As urbanization spreads, the monkeys' territory and access to food are also reduced. Because of these, many of these primates migrate to the larger urban centers in search of new shelters and resources (Auricchio, 1995; Pinto e Roberto, 2016).

As a result, urgent and emergency cases in these mammals have become more frequent, since they are subject to electrocution from electric power transmission lines, attacks by domestic animals, and physical injuries (intentional or accidental) such as poisoning, bruises, lacerations, burns, vehicular accident, and fractures (Gering et al., 2017). Therefore, veterinarians face a challenge when encountering exotic animals in routine practice, especially when surgical intervention is required, depending on the severity of the patient's clinical condition.

*Recebido em 25 de fevereiro de 2019 e aceito em 4 de junho de 2019.

**Federal Rural University of Amazonia (UFRA), Faculty of Veterinary Medicine, Institute of Animal Health and Production, Belém, Pará, PA, Brazil.

***State University of Pará (UEPA), Faculty of Medicine, Belém, Pará, PA, Brazil.

${ }^{* * * *}$ Federal Rural University of Amazonia (UFRA), Postgraduate Program in Animal Health and Production in the Amazon, Belém, Pará, PA, Brazil.

${ }^{* * \star * *}$ Federal Rural University of Amazonia (UFRA), Faculty of Veterinary Medicine, Institute of Animal Health and Production, Belém, Pará, PA, Brazil.

${ }^{* * * * *}$ Federal Rural University of Amazonia (UFRA), Faculty of Veterinary Medicine, Institute of Animal Health and Production, Belém, Pará, PA, Brazil.

Email: ebranco.ufra@gmail.com Corresponding author. 
Surgical intervention usually requires anesthesia, which should be administered with caution in order to ensure the animal's safety, and a common and effective technique with respect to safety is epidural anesthesia. This is a technique frequently used for the administration of anesthetics in the epidural space, which is the area between the dura mater and the vertebral canal. It is usually effective and fast, with minor side effects, and also promotes intraoperative and postoperative analgesia, reducing the post-surgical stress response (Weissman, 1990; Mcmurphy, 1993; Fantoni e Cortopassi, 2009).

The location of administration of the drug in the epidural space varies with the animal species and the selected site at the base of the medullary cone. However, the use of sites caudal to the medullary cone provides more safety during epidural administration, as it avoids lesions in the spinal cord (Hilbery, 1994).

In light of the above information, we decided to expand upon the morphological records of this species and provide important information on anesthetic protocols, epidural analgesics, and laboratory tests for medical and surgical operations in wild animals. This information would not only offer greater security to veterinarians when it comes to the safe execution of epidural protocols, but also provide greater patient comfort.

\section{Material and methods}

The study protocol was approved by the Ethics and Research Committee on Animals of the Evandro Chagas Institute Ananindeua/PA (CEPAN/IEC/SVS/MS), under the authorization number 008/2010.

We used five young female specimens of the feline night monkey (Aotus azarae infulatus) from the National Centre of Primates (CENP), Ananindeua- Pará, which were frozen after death by natural causes and sent to the Animal Morphological Research Laboratory of the Federal Rural University of Amazonia (LaPMA ( UFRA).
The specimens were thawed in running water for two hours and fixed using intramuscular and intracavitary infusions of aqueous $10 \%$ formaldehyde solution, with subsequent submersion of the animals in the same solution for a minimum of seven days.

Radiographs were initially taken at the veterinary hospital of the Federal Rural University of Amazonia-UFRA, observing the standards of radiological protection, followed by positioning the animals in the right lateral decubitus, under left lateral-lateral projections, using the X-ray machine Intecal ${ }^{\circledR}$, model CR-7, with $100 \mathrm{kV}$ power, maintaining a focus-film distance of $100 \mathrm{~cm}$, a current of $100 \mathrm{~mA}$, and exposition time of 0.4 seconds. For the radiologic exams, exposure factors of the order of $55 \mathrm{kV}$ and $2.5 \mathrm{~mA}$ were used.

The specimens were then dissected using basic surgical instruments. This involved incision and bending of the skin, the subcutaneous tissue, and the musculature dorsal to the vertebral column, thereby exposing the lumbar and sacral vertebrae. Subsequently, the spinous processes and part of the vertebral arches were removed to ensure adequate exposure of the medullary tissue and photodocumentation.

The nomenclature adopted was based on the Veterinary Anatomical Nomenclature (INTERNATIONAL COMMITTEE ON VETERINARY GROSS ANATOMICAL NOMENCLATURE, 2017).

\section{Results and discussion}

We found eight lumbar vertebrae and three sacral vertebrae (Figure 1), in each of the five night monkeys analyzed, and the medullary cone was consistently caudal to the lumbar intumescence, with a well elongated pattern, and an average length of $7.5 \mathrm{~cm}$

Its base was located on the fifth lumbar vertebra (L5) and its apex on the third sacral vertebra (S3). The cone was immediately

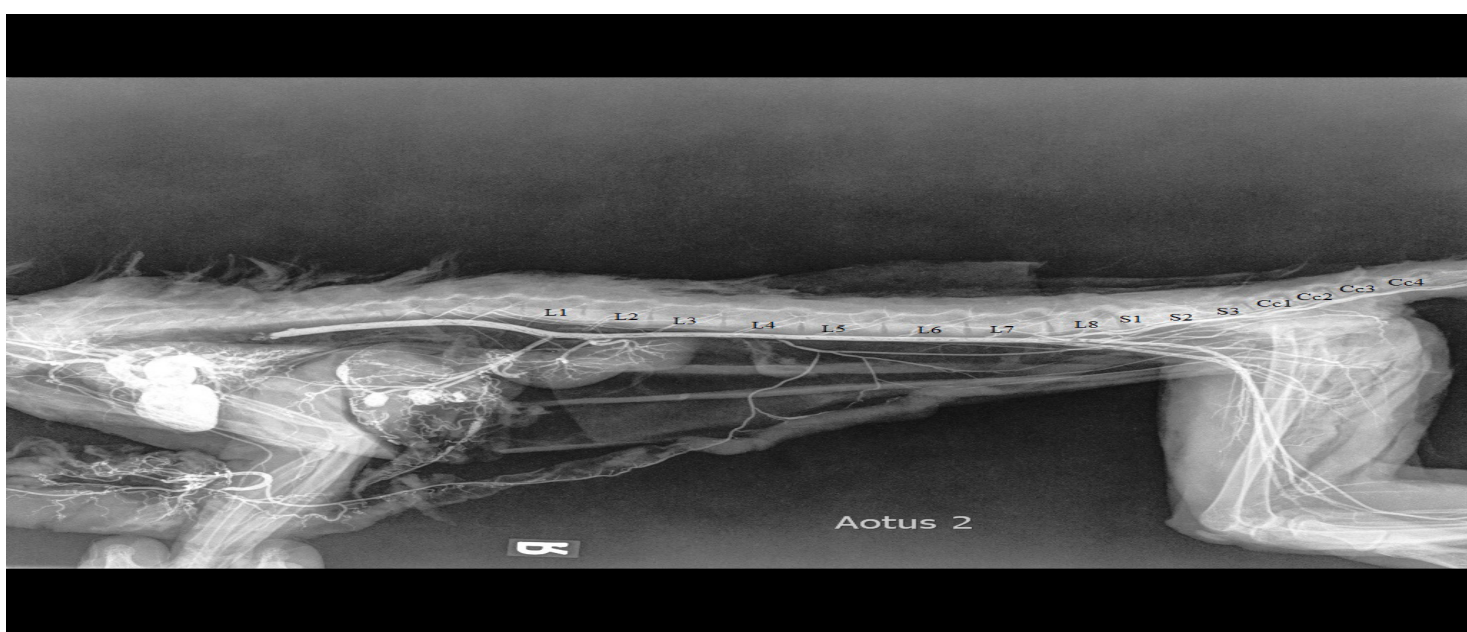

Figure 1: Radiographic image of Aotus azarae infulatus in the right lateral-lateral position. Note the presence of eight lumbar vertebrae (L1-L8), three sacral vertebrae (S1-S3), and the first coccygeal vertebrae (Cc1-Cc4). 
covered by the dura mater, which showed no prolongation. Consequently, no dural sac was formed (Figure 2).

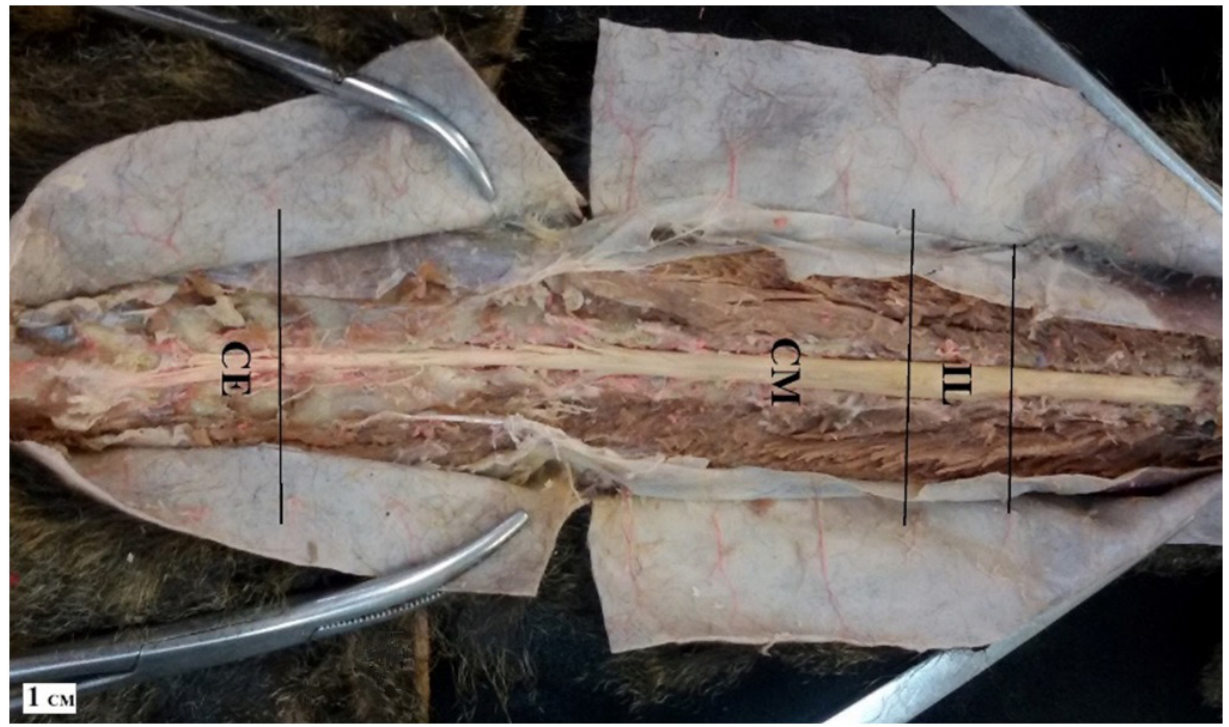

Figure 2: Photomacrographic image of the vertebral column of Aotus azarae infulatus (Dorsal view). Note the topography of the medullary cone (CM), interposed between the lumbar intumescence (IL) and cauda equina (CE). Scale bar: $1 \mathrm{~cm}$.

The absence of the dural sac may be of concern, since the risk of spinal cord injury and consequent neurological injury increases if the anesthesiologist lacks the skill and precision to administer epidural anesthesia (Ganem, 2006). In the case of the night monkey, the fact that it does not have the dural sac, the anesthesiologist may inadvertently access the subarachnoid space (O'Hearn and Wright, 2011).

Conversely, the topography of the medullary cone of the night monkey favors the epidural approaches in these individuals, as it was described by Silva et al (2013) for the common marmoset and Cordeiro et al (2014) for capuchin monkeys. Both studies consider the epidural space to be a safe area for both epidural anesthesia and other procedures in nonhuman primates, regardless of the presence or absence of the dural sac in these species, decreases central sensitization, intraoperative inhalant and opioid requirements, the use of postoperative rescue analgesia and plasma concentrations of stress response biomarkers during surgery (Romano et al., 2016, Steagall et al., 2017).

Due to the dearth of studies regarding the medullary cone, further studies with the same objective as the present study are warranted. Further studies involving other species of nonhuman primates are also recommended due to the importance of knowledge regarding epidural approaches in order to determine the definitive sites of anesthetic drug application, and improve the veterinarian's performance in clinical and wildlife surgery.

Comparing the records of the topography of the medullary cone in other non-human primates, we identified the black-striped capuchin (Cebus apella) with a medullary cone ranging from $1.7 \mathrm{~cm}$ to $3.51 \mathrm{~cm}$ in length and located between L2 and L5 (Cordeiro et al., 2014); the squirrel monkey (Saimiri sciureus) with a medullary cone measuring $3.3 \mathrm{~cm}$ and located between $L 7,8$ and S3, Cc1 (Lima et al., 2011a); and the red-handed tamarin (Saguinus midas) with a medullary cone measuring $5.14 \mathrm{~cm}$ and located between L4 and S2 (Martins et al., 2013).

These data provide definitive evidence that the size of the animal has no relationship with the topography and length of the medullary cone, especially when we notice that the tamarin is smaller than the capuchin and the squirrel monkey but has a larger medullary cone when compared to these two non-human primates. The size of the animal (the tamarin and the night monkey) was in no way proportional to the length of the medullary cone. This further underscores the importance of knowledge of the topography of the medullary cone of each species in order to perform epidural procedures safely, rather than merely using an approximation or estimation, however, identification of correct needle placement in the epidural space varies with the experience of the operator (Garcia-Pereira et al., 2010), because, epidural administration of drugs is a relatively simple technique. If the technique is performed with care, taking into consideration the relevant anatomy of the epidural space (Garcia-Pereira, 2018).

Although few similar studies are available in the literature, we seek to compare our results with those of previous studies in other wild mammals, such as the report by Branco et al (2013) on the topography of the medullary cone of the tayra (Eira barbara), which had six lumbar vertebrae and three sacral vertebrae, a lumbar intumescence located between $\mathrm{L} 2$ and $L 4$, and a medullary cone between L4 and L6, measuring $4.31 \mathrm{~cm}$. The measurement result is intriguing, as the tayra is definitively larger and burlier than the night monkey.

This discrepancy persists when we compare our morphometric findings to the ones reported by De Santa Brígida et al (2010) regarding the medullary cone in ocelots (Leopardus pardalis). Their medullary cone is located between L4 and S3, similar to that observed in the night monkey, and measures $8.5 \mathrm{~cm}$, which is only $1 \mathrm{~cm}$ longer than that in the feline night monkey, a primate much smaller than the ocelot. This demonstrates once again that the location of the medullary cone has no relationship with the size of the animal. Thus, a topographic mapping of this structure is necessary for epidural anesthesia to be correctly administered.

A similar discrepancy exists when we observe the measurement and topography of the medullary cone of the gray brocket (Mazama gouazoubira), which starts at L2-L3 and ends at S1-S2, measuring $4.6 \mathrm{~cm}$ in length (Lima et al., 2010). This is an animal many times larger than the night monkey, yet its medullary cone is much shorter.

On analyzing the medullary cone in a group of peculiar wild mammals like the Xenarthrans, in particular the brown-throated sloth (Bradypus variegatus), it can be observed that the medullary cone is located at a more caudal level (L3-S1). Although this animal is bigger than the night monkey, its medullary cone is shorter, measuring $2.7 \mathrm{~cm}$ (Lima et al., 2011b). 


\section{Conclusion}

In light of the topographic findings in the feline night monkey, the recommended site for administration of epidural anesthesia in this species is the sacrocaudal region, which has easily palpable intervertebral space, taking into consideration the technique, appropriate needle and consideration the relevant anatomy of the epidural space. In this context, and considering the size of this species, we suggest that the epidural access of the region occurs with the animal in the ventral decubitus, with the pelvic limbs without support.

\section{Acknowledgements}

The authors thank the National Centre of Primates (CENP)/Ananindeua-PA for their support.

\section{References}

AURICCHIO, P. Primatas do Brasil. São Paulo: Terra Brasilis Comércio de Material Didático e Editora, 1995, 168p.

BICCA-MARQUES, J.C.; SILVA, V. M.; GOMES, D. F. Ordem Primates. In.: REIS, N.R.; PERACCHI, A.L.; PEDRO, W.A.; LIMA, I.P. (eds.) Mamíferos do Brasil. Londrina: Sociedade Brasileira de Zoologia, 2006, p. 101-148.

BRANCO, E.; LINS, F.L.M.L.; PEREIRA, L.C.; LIMA, A.R. Topografia do cone medular da irara (Eira barbara) e sua relevância em anestesias epidurais. Pesquisa Veterinária Brasileira, v.33, n.6, p.813-816, 2013.

GANEM, E.M. Complicações neurológicas da anestesia peridural e subaracnóidea. In: CAVALCANTI, I.L.; CANTINHO, F.A.F.; ASSAD, A. (eds.) Medicina Perioperatória. Rio de Janeiro: Sociedade de Anestesiologia do Estado do Rio de Janeiro, 2006, p.197-201.

CORDEIRO, J.F.; SANTOS, J.R.S.; DANTAS, S.B.A.; FONSECA, S.S.; DIAS, R.F.F.; MEDEIROS, G.X.; NOBREGA NETO, P.I.; MENEZES, D.J.A. Anatomia do cone medular aplicada à via epidural de administração de fármacos em macacos-prego (Sapajus apella). Pesquisa Veterinária Brasileira. v.34, Supl.1, p.29-33, 2014.

DE SANTA BRÍGIDA, S.S. BRANCO, E.; PINHEIRO, L.P.; MARTINS, D.M.; ARAÚJO, E.B.; MELUL, R.; LACRETA JR, A.C.C.; MENESES, A.M.C.; SOUZA, A.C.B.; PEREIRA, L.C.; FIORETTO, E.T.; LIMA, A.R. Topografia do cone medular da jaguatirica (Leopardus pardalis). Acta Veterinaria Brasilica, v.4, n.1, p.51-54, 2010.

FANTONI, D.T.; CORTOPASSI, S. R. G. Anestesia em cães e gatos. 2 ed. São Paulo: Roca, 2009. 622p.

GARCIA-PEREIRA, F.L.; HAUPTMAN, J.; SHIH, A.C.; LAIRD, S.E.; PEASE, A. Evaluation of electric neurostimulation to confirm correct placement of lumbosacral epidural injections in dogs. American Journal of Veterinary Rsearch. v.71, p.157-160, 2010.

GARCIA-PEREIRA, F Epidural anesthesia and analgesia in small animal practice: An update. The Veterinary Journal. v. 242, p.2432, 2018.

GERING, A.P.; NASCIMENTO, M.N.S.; LOPES, C.T.A.; DOMINGUES, S.F.S. Atendimento emergencial de Tamandua tetradactyla (linnaeus, 1758) vítima de eletrocussão: relato de caso. Jornal Latinoamericano de Medicina Veterinária de Emergência y Cuidados Intensivos. v.9, n.1, p.1-7, 2017.

HILBERY, A.D.R. Manual de anestesia de los pequeños animales. Zaragoza: Acribia, 1994. 153p.

INTERNATIONAL COMMITTEE ON VETERINARY GROSS ANATOMICAL NOMENCLATURE. Nomina Anatômica Veterinária. 6th Edition. Hannover: Editorial Committee, 2017. 178p.
LIMA, F.C.; SANTOS, A.L.Q.; LIMA, B.C.; Vieira, L.G.; Hirano, L.Q.L. Topographic anatomy of the spinal cord and vertebra medullary relationships in Mazama gouazoubira Fisher, 1814 (Artiodactyla; Cervidae). Acta Scientiarum. Biological Sciences. v.32, n.2, p.189-194. 2010.

LIMA, A.R. FIORETTO, E.T.; FONTES, R.F.; IMBELONI, A.A., MUNIZ, J.A.P.C. BRANCO, E. Caring about medullary anesthesia in Saimiri sciureus: the conus medullaris topography. Anais da Academia Brasileira de Ciências. v.83, n.4, p.1339-1344, 2011a.

LIMA, A. R. COSTA, A.M.; FIORETTO, E.T.; SANTIAGO, H.R.V.; CARMO, D.C.; BRANCO, E. Topografia do cone medular da preguiça. Pesquisa Veterinária Brasileira, v.31, n.7, p.627-630, 2011b.

MARTINS, D.M. PINHEIRO, L.L.; LIMA, A.R.; PEREIRA, L.C.; BRANCO, E. Topografia do cone medular do sauim (Saguinus midas). Ciência Rural, v.43, n.6, p.1092-1095, 2013.

MCMURPHY, R.M. Postoperative epidural analgesia. Veterinary Clinics of North America: Small Animal Practice, v.23, n.4, p.703716, 1993.

O'HEARN, A.K.; WRIGHT, B.D. Coccygeal epidural with local anesthetic for catheterization and pain management in the treatment of feline urethral obstruction. The Journal of Veterinary Emergency and Critical Care (San Antonio), v.21, p. 50-52. 2011.

PINTO, L.F.; KZAM, A.L. A Amazônia Decifrada. 1. ed. Belém: Smith, v.1. 2012. 266p.

PINTO, T.; ROBERTO, I.J. Distribution extension of Aotus azarae infulatus (Kuhl, 1820) (Primates: Aotidae) and first record from the Caatinga biome. Check List, v.12, n.4, p.1-3, 2016.

ROMANO, M.; PORTELA, D.A.; BREGHI, G.; OTERO, P.E. Stress-related biomarkers in dogs administered regional anaesthesia or fentanyl for analgesia during stifle surgery. Veterinary Analgesia, v.43, p.44-54, 2016.

SILVA, L.C.S.; BARROSO, C.E.; PAVANELO JUNIOR, V.; BOMBONATO, P. B. Topografia vértebro-medular em sagui-detufo-branco (Callithrix jacchus, LINNAEUS 1758). Ciência Animal Brasileira, v.14, n.4, p.462-467, 2013.

STEAGALL, P.V.M.; SIMON, B.T.; TEIXEIRA NETO, F.J; LUNA, S.P.L. Na update on drugs used for lumbosacral epidural anesthesia and analgesia in dogs. Frontiers in veterinary Science, v.4, p.68, 2017.

WEISSMAN, C. The metabolic response to stress: an overview and update. Anesthesiology, v.73, 308-327, 1990. 